\title{
The Personal Sense of Efficacy as an Indicator of Efficiency of Student Teaching of Physical Education and Sports
}

\author{
Ayman Guemri1,2, Nejah Kacem³ ${ }^{\text {, Chokri Naffeti2 }}{ }^{2}$ Mourad Bahloul ${ }^{4}$ \\ ${ }^{1}$ State, Culture and Change of Society, Higher Institute of Sport and Education Physics Ksar Said, Mannouba, Tunisia \\ ${ }^{2}$ Higher Institute of Sport and Physical Education of Sfax, Sfax, Tunisia \\ ${ }^{3}$ Group for the Study of Development and Social Environment (GEDES), Faculty of Human and Social Science of Tunis, Tunis, Tunisia \\ ${ }^{4}$ Higher Institute of Business of Sfax, Sfax, Tunisia \\ Email:kacemnejah@gmail.com
}

How to cite this paper: Guemri, A., Kacem, N., Naffeti, C. \& Bahloul, M. (2016). The Personal Sense of Efficacy as an Indicator of Efficiency of Student Teaching of Physical Education and Sports. Advances in Physical Education, 6, 269-282. http://dx.doi.org/10.4236/ape.2016.64028

Received: July 12, 2016

Accepted: September 23, 2016

Published: September 26, 2016

Copyright $\odot 2016$ by authors and Scientific Research Publishing Inc. This work is licensed under the Creative Commons Attribution International License (CC BY 4.0).

http://creativecommons.org/licenses/by/4.0/ (c) (i) Open Access

\begin{abstract}
The objective of this study is to look for the effect of student teaching on the personal sense of efficacy of the intern of sports and physical education teacher. For calculating this effect, it has used the French version of the questionnaire by Perrault (2008) for trainee teachers and semi maintenance policy for educational advisers. Our sample consists of 402 trainee teachers and 10 counsellors of higher Institute of sport and physical education of Sfax. The results show that student teaching of sports and physical education increases the feeling of self efficacy in the trainee contrary to the opinion of counsel that shows as the student teaching is not significant effect. We can explain our result by Hoy Woolfolk notice, (1990); Gorrell \& Hwang (1995); Mulholland, Dorman, \& Odgers (2004), which show that the beliefs of efficiency increase among future teachers during curriculum but there are other research that shows such as Plourde studies (2002), which shows that there is no effect of practice teaching on the beliefs of the effectiveness of future teachers and they attribute this result downward and the realization of the difficulties in teaching.
\end{abstract}

\section{Keywords}

Personal Sense of Efficacy, Student Teaching, Physical Education and Sports

\section{Introduction}

The personal sense of efficacy is an important index to assess the pedagogical teaching course. Romano (1996) to "consider a sense of personal effectiveness as an indicator of the effectiveness of a training". The first researcher who applied the theory of self- 
efficacy is Albert Bandura (1977). It shows an important role of self-efficacy beliefs in the majority of acts of human beings. Research in educational psychology still attached great importance to the concept of self-efficacy of the teacher (teacher efficacy). (Gaudreau et al. 2012). Tschannen-Moran et al. (1998) noted the hundreds of books or articles on the subject. Armor et al. (1976) and Berman et al. (1977) are the first researchers who apply the theory of efficacy by Bandura (1977) teachers. In this regard, several studies show that personal sense of efficacy increases positively during an educational internship (Housego, 1992; Hoy et al. 2005). Other studies have highlighted "correlations between efficacy and skills and suggest that the confidence of an individual to carry out a task may be induced as a result of training" (Perrault, 2010: p. 2). All this leads us to look at the evaluation of the educational course through the sense of self efficiency or the sense of personal efficacy. Despite the importance of student teaching in the training of teachers of physical education and sport, which is the fruit of 3 years of academic training, it has not yet assessed the influence of this internship on the sense of teacher competence and in particular skills needed for education. The objective of our research is to use the sense of self efficiency as an indicator to evaluate the efficiency of the teaching course of EPS. All this leads us to ask these questions: the teaching course of physical and sports education improves it the personal sense of efficacy among trainee teachers?

\subsection{Personal Sense of Efficiency on the Teacher}

Several studies that show the beneficial effect of sense of self efficiency on the behavior of the teacher. These studies have shown that more mathematics teachers who have a strong SAE, "More they are best in their presentations lesson", "More they are best in their class management", "More they are best in their questions to the students", (Saklofske et al., 1988), "More they have occupational humanistic beliefs" (Enochs et al., 1995). Romano (1996) to consider a sense of personal effectiveness as an indicator of the effectiveness of training. Piccoli et al. (2001) demonstrates also that it is important to estimate also the perceptions of learners in their own capacities, within the framework of the evaluation of the effectiveness of a training. From these findings, there is that sense of self efficiency is a good indicator to assess the quality of training. The quality of training is measured from the necessary skills for education (Perrault 2010). The notion of competence lies in several areas such as psychology, sociology and even the science of education, especially physical education. Perrenoud (2013) defines competence as the "ability to mobilize various cognitive resources to cope with a type of situations”. Also, Jonnaert (2002) defines the concept of jurisdiction as a set of resources that an individual uses in a situation to achieve an action. According to Henri Boudreault (2002) a skill is a mobilizable knowledge (knowledge, know-how, skills) to resolve a problem situation. According to Boudreault (2002), the jurisdiction is the synergistic knowledge articulation, attitudes and skills (know-how).

\subsection{The Student Teaching of EPS}

In fact, the course represents "an opportunity to live a significant relationship with a 
mentor that can serve as a model, guide, comment on situations and interventions" (Gervais, 1999). The course teaching of eps is deroulelent in different school hotel of the city of Sfax during a school year due to a single meeting by a week during the entire school year. The behavior of the trainee teacher occupies a very important place for the success of the educational course of EPS. According to Jain (2004), the educational course "it's live event in which it comes to proceed by identity shifts which are closely related to the redefinition of its role and the reconsideration of the knowledge to teach (Jain, 2004). Shkedi et al. (2004), the pedagogical internship represents an opportunity for trainee teachers to confront the "real world of education" (Shkedi \& Laron, 2004) and facilitating the integration into the profession (Bullough et al., 2003). All trainee teacher has rights and duties that it must comply with in his teaching. In addition, it must have the documentation and the necessary equipment to perform its task. The trainee teacher of EPS has several rights, among which: have a school or is going on the course with his own choice by order of merit, having supervision on the part of a coach of a school teacher, received educational instructions necessary to the student in each session, have a degree of autonomy in his teaching and intervene only in emergencies, have an evaluation objective away from discrimination by sex (the region...), help to integrate into the school and fit into the educational team and have the information necessary to ensure the smooth running of the stage in a better condition. The trainee teacher has duties that it must abide by them. At the level of his teaching, the trainee teacher should: avoid any sort of moral or physical violence towards the student. In case of problems, it must use the framer teacher to find a solution, respecting the rules of the school, take into account the number of weeks of work, the days holidays and weeks blocked, come in presentable sportswear and avoid all the stuff that can cause students: cutting horses, girls makeup...). It is prohibited the trainee teachers taught in absence of the framer teacher who is the first head of the internship. In addition the trainee teacher must have a course to teach it in the class or locker room in case of bad weather, being relatively objective, clear and credible in assessing and avoiding any kind of discrimination (by sex, region, race...), apply the official instructions, refer to the content of the EPS programs, take into account specificities of the establishment and its cyclic distribution Establish its own cyclical programming from the information collected during the competition no. 1 (diagnostic assessment) and possibly meet the pedagogical innovations. In addition to these rights, the trainee teacher must maintain documentation and the necessary equipment to teach.

\section{Methodology}

The measure used in this study tool is the personal self-efficacy questionnaire for teachers CFC and semi maintenance policy for educational advisers.

\subsection{The Questionnaire}

The questionnaire used is the personal sense of effectiveness of Perrault (2010). This tool addresses issues relating to the acquisition of the skills necessary for teaching. This 
questionnaire is composed of 10 dimensions, represents 10 skills, and each jurisdiction has statements according to Table 1.

The questionnaire items are ordered in the questionnaire under the following order (Table 2).

According to the methodology of Gérard (2003) for the assessment of the efficiency of student teaching, this methodology is to estimate the level of satisfaction a 14 aide on a scale of 8 choice, for each of the 10 competencies ranging from "not at all effective" to "very effective". The sense of self-efficacy questionnaire is made up of 33 items (see annexes). Prior to the distribution of questionnaire? It was a test on a sample reduced

Table 1. Classification of competences.

\begin{tabular}{|c|c|c|c|}
\hline Compétence & Number of sous-competence & Type of jurisdiction & Field of competence \\
\hline Compétence & 3 & Academic skills & $\begin{array}{l}\text { The exercise of professional } \\
\text { responsibility and ethics }\end{array}$ \\
\hline Compétence 2 & 3 & Academic skills & $\begin{array}{l}\text { The exercise of professional } \\
\text { responsibility and ethics }\end{array}$ \\
\hline Compétence 3 & 2 & Academic skills & $\begin{array}{l}\text { The exercise of professional } \\
\text { responsibility and ethics }\end{array}$ \\
\hline Compétence 4 & 5 & Skills at the heart of the business & $\begin{array}{l}\text { The exercise of professional } \\
\text { responsibility and ethics }\end{array}$ \\
\hline Compétence 5 & 3 & Skills at the heart of the business & The act of teaching \\
\hline Compétence 6 & 3 & Skills at the heart of the business & $\begin{array}{l}\text { Taking account of the social } \\
\text { and educational context }\end{array}$ \\
\hline Compétence 7 & 3 & Skills at the heart of the business & The act of teaching \\
\hline Compétence 8 & 3 & Cross-curricular competencies & The act of teaching \\
\hline Compétence 9 & 4 & Cross-curricular competencies & $\begin{array}{l}\text { Taking account of the social and } \\
\text { educational context }\end{array}$ \\
\hline Compétence10 & 4 & Cross-curricular competencies & $\begin{array}{l}\text { The exercise of professional } \\
\text { responsibility and ethics }\end{array}$ \\
\hline
\end{tabular}

Table 2. Order of the items in the scale.

\begin{tabular}{cc}
\hline $\mathrm{N}^{\circ}$ & Items \\
\hline Compétence 1 & $4,6,12$, \\
Compétence 2 & $7,10,11$, \\
Compétence 3 & 1,2, \\
Compétence 4 & $15,16,20,22,24$, \\
Compétence 5 & $18,19,26$, \\
Compétence 6 & $27,30,33$ \\
Compétence 7 & $14,21,23$, \\
Compétence 8 & $13,17,25$, \\
Compétence 9 & $28,29,31,32$, \\
Compétence 10 & $3,5,8,9$ \\
\hline
\end{tabular}


to ensure proper understanding of questionnaire. It took into account the comments of teachers and subsequently, we changed a few expressions of some questions so that they correspond to the direction of our research, including the specificity of teaching physical education course.

\subsubsection{Data Collection}

The distribution of the questionnaires will be held during the month of May, 2014 and may 2015 at the higher Institute of sport and physical education of Sfax to the student's graduating class (3rd year fundamental licence in physical education). This questionnaire is distributed just before discontinuation of courses in free time. We took care to explain some points to help respondents to choose the answer that suits them.

\subsubsection{Study Population}

Each student in 3rd year Bachelor EPS must perform a teaching internship of teaching of EPS in a primary school, a preparatory school or in a school of a session per week (Tuesdays and Thursdays) during the entire school year (Table 3 ).

Our population is composed of. Our sample consists of 402 trainee teachers of the higher Institute of sport and physical education of Sfax who participated voluntarily in this study after an eight month internship in different schools of the city of Sfax (Figure $1)$.

\subsubsection{Statistics Data Analysis}

For processing the response, statistical analysis is performed on a PC using the software “excel".

Hainaut (1975) when uniformity is less than a $15 \%$, that is, the population is homogeneous. While when uniformity is greater was $30 \%$, that is, the population is heterogeneous. According to Gerard (2003), told that it is a learning effect the when the average relative gain exceeds $40 \%$.

Table 3. Distribution of hourly volume of student teaching (Guemri et al. 2016).

\begin{tabular}{cccccc}
\hline & & Student 1 & Student 2 & Student 3 & Student 4 \\
\hline Tuesday & $8 \mathrm{~h} \mathrm{a} 10 \mathrm{~h}$ & Teaching & Observation & Free & Free \\
& $10 \mathrm{~h} \mathrm{a} 12 \mathrm{~h}$ & Observation & Teaching & Free & Free \\
Thursday & $8 \mathrm{~h} \mathrm{a} 10 \mathrm{~h}$ & Free & Free & Teaching & Observation \\
& $10 \mathrm{~h} \mathrm{a} 12 \mathrm{~h}$ & Free & Free & Observation & Teaching \\
\hline
\end{tabular}

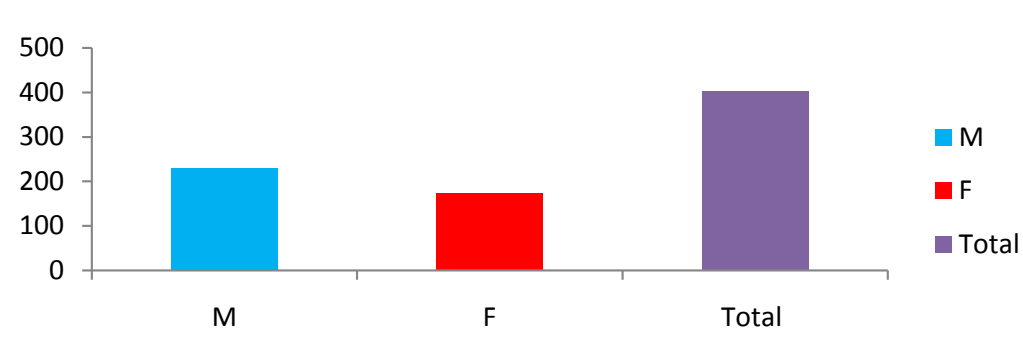

Figure 1. Distribution of population by sex. 


\subsection{Maintenance}

Maintenance used in this research is the semi maintenance policy. The latter represents a blend between the closed maintenance and the open. Our maintenance consists of 10 questions revolves around the 10 skills for teaching. which are respectively: official State and how ethical and responsible act, mastering the French to teach communication, mastering disciplines and have a good general culture, design and implement his teaching and organising the work of the class, taking account of the diversity of students, student assessment, master the technologies of information and communications work as a team and cooperate with parents and school partners develop and innovate.

\subsubsection{Maintenance Guide}

According to Guittet (2008) the interview guide necessarily contains the following steps:

Come forward and give an idea about the framework and objectives of maintenance,

-Fix an appointment for servicing;

-Have permission for audio recording (voice);

-Give an idea on the number of questions;

-Estimate the duration of the maintenance.

\subsubsection{Content Analysis}

In our study, we used the content analysis method to analyze the result. This method is inspired by Philippe Wanlin (2007) which is to do a reading of the interview responses and classifying it according to specific themes.

\section{Results}

\subsection{The Effect of Learning on the Personal Sense of Efficiency of the EPS Trainee Teacher}

According the results (Table 4) yet, we note that there is a positive learning effect

Table 4. Learning effect on the sense of self efficiency of trainee teacher of EPS.

\begin{tabular}{ccc}
\hline Compétence & GMB & GRM \\
\hline C01 & 1.18 & $44.85 \%$ \\
C02 & 1.56 & $46.20 \%$ \\
C03 & 1.73 & $49.08 \%$ \\
C04 & 1.74 & $53.94 \%$ \\
C05 & 1.63 & $52.58 \%$ \\
C06 & 1.07 & $31.06 \%$ \\
C07 & 1.68 & $46.40 \%$ \\
C08 & 1.1 & $29.02 \%$ \\
C09 & 1.04 & $23.41 \%$ \\
C10 & 1.33 & $37.71 \%$ \\
The personal sense of efficacy & 1.406 & 41.43 \\
\hline
\end{tabular}


(average relative gain) on the sense of self efficiency with a relative gain of GRM $=41.43 \%$ (above $40 \%$ ). This indicates that trainee teachers of EPS believe have actually improved during the teaching course of EPS.

\subsection{Results of Maintenance on Feeling of Skills}

Table 5 shows the presence of 4 skills that have progressed positively during student, teaching which are respectively: jurisdiction 1: acting as a civil servant of the State and the guardian of ethics (88.87\%), skill 2: the mastery of the French language to teach and communicate $(75.76 \%)$, competence 5: designing and implementing his own and communication technologies (42.32\%); and 6 skills that are decreased negatively during student teaching which are respectively: jurisdiction 3: the mastery of disciplines received Øreceived in his/education in general (66.67\%), skill 4: designing and implementing his own teaching 『plans (57.69\%), jurisdiction 6: taking into account the diversity of the students (51.61\%), jurisdiction 7: evaluating students (81.58\%), jurisdiction 9: working as a team and cooperating with parents and school peers (47.62\%) and Competence 10: forming and innovating (51.72\%). So according to the Advisor, trainee teachers have acquired no more than $40 \%$ skills and subsequently the educational course of EPS does not a good command of this $60 \%$ competency.

\section{Discussion}

According to the results yet, we note that trainee teachers of EPS estimate have actually improved during the teaching course of EPS regards the personal sense of efficacy. Our result corroborate with several studies: Hoy Woolfolk (1990); Gorrell \& Hwang (1995); Mulholland, Dorman, \& Odgers (2004) show that the beliefs of efficiency increase among future teachers during curriculum or teaching internship and assign the results to the experience of the master during the student teaching in teachers who is among the sources of sense of self efficiency. "As well as other factors such as observation and

Table 5. Results of maintenance on feeling of skills.

\begin{tabular}{ccc}
\hline $\mathrm{N}^{\circ}$ & Defined & Percentage \\
\hline Competence 1 & + & $88.87 \%$ \\
Competence 2 & + & $75.76 \%$ \\
Competence 3 & - & $66.67 \%$ \\
Competence 4 & - & $57.69 \%$ \\
Competence 5 & + & $57.14 \%$ \\
Competence 6 & - & $51.61 \%$ \\
Competence 7 & - & $81.58 \%$ \\
Competence 8 & + & $42.32 \%$ \\
Competence 9 & - & $47.62 \%$ \\
Competence 10 & - & $51.72 \%$ \\
\hline
\end{tabular}


social learning (application experiences) and the encouragement of teachers framer" (Ramey-Gassert Shroyer, 1992; Scharmann Hampton, 1995; Huinker Madison, 1997). However, the differences in these studies may be related to how effectiveness was measured (Tschannen-Moran \& Woolfolk Hoy, 2002), the important phase of the effect of socialization (Hoy Woolfolk, 1990) and fluctuating experiences in training of teachers (Ginns et al., 1995; Ashton Webb, 1986). It can be concluded that it is important to determine the beliefs of self-efficacy of teachers prior to use because it is difficult to change beliefs once the personal sense of efficacy are trained (Yalcin, 2011). But our result is not consistent with several studies:

Yylmaz and Cavap (2007) "have studied the effect of the practice of the teaching of teachers' interns on the beliefs of the effectiveness of two different universities in Izmir, Turkey". "They have concluded that teaching practice experience has no effect on future teachers in primary education on the beliefs of scientific effectiveness. (Plourde, 2002) showed that teaching practice has no effect of practice of teaching on the beliefs of the effectiveness of future teachers and they attribute this result downward and the realization of the difficulties in teaching. Schoeneberger et al. (1986); Enochs \& Riggs, (1990), Riggs (1991), Mulholland (2000), Appleton (2003), Mulholland (2004) show that teacher trainees do not have the confidence to teach and it decreases their personal effectiveness in primary and secondary education. Gencer et al. (2007); Ginns (1999) found that the practical training in teaching was not an important factor in the personal sense of efficacy. It is concluded that our research opens many perspectives: first, increase the hourly volume of student teaching at two levels: at the level of the number of outputs ( 2 outputs per week instead of one output) and at the level of the number of semesters ( 3 semesters of course instead of 2 semesters), to ensure a large number of repetition as a saying by forging, it becomes will forge, then, to reduce the number of students by teachers to improve the quality of coaching which allows to better detect failures in different skills and subsequently to improve teaching skills, then to involve teachers coaches in evaluation of educational internships as a partner in the supervision. Then, establishing criteria well determined in the choice of framers and pedagogical advisors to be able to properly frame the trainee teacher: e.g. introduction of a (certificate of further study) CEC or professional master's degree in educational Advisor at the ISSEPS breasts. Again, designing a repository of jurisdiction for the Tunisian population taking into account the realities of education in general and the specificity of physical education as a subject. Finally, paving the way for further research to find methods necessary to improve the different types of skills necessary for the teaching of physical education.

\section{References}

Appleton, K. (2003). How Do Beginning Primary School Teachers Cope with Science? Toward an Understanding of Science Teaching Practice. Research in Science Education, 33, 1-25. http://link.springer.com/article/10.1023/A\%3A1023666618800

Ashton, P. T., \& Webb, R. B. (1986). Making a Difference: Teachers' Sense of Efficacy and Student Achievement. New York: Longman. 
Bandura, A. (1977). Self-Efficacy: Toward a Unifying Theory of Behavioral Change. Psychology Review, 84, 191-215. https://www.uky.edu/ eushe2/Bandura/Bandura1977PR.pdf

Berman, P. et al. (1977). Federal Programs Supporting Educational: Factors Affecting Implementation and Continuation. Santa Monica, CA: The Rand Corporation.

http://www.rand.org/content/dam/rand/pubs/reports/2005/R1589.7.pdf

Boudreault, H. (2002). Le facteur Q.C.D. Etreconfortableendehors de sa zone de confort. Université de quebecmontreal-departementd' education et formation continue, 23. http://www.uqar.ca/files/pedagogie universitaire/qcd2.pdf

Bullough, J. D. (2003). Lighting Answers: Light Emitting Diode Lighting Systems. Troy, NY: National Lighting Product Information Program, Lighting Research Center, Rensselaer Polytechnic Institute.

Enochs, L. G., \& Riggs, I. M. (1990). Further Development of an Elementary Science Teaching Efficacy Belief Instrument: A Preservice Elementary Scale. School Science \& Mathematics, 90, 694-706. http://onlinelibrary.wiley.com/doi/10.1111/j.1949-8594.1990.tb12048.x/abstract

Enochs, L.G. et al. (1995). The Relationship of Pupil Control to Preservice Elementary Science Teacher Self-Efficacy and Outcomes Expectancy. Science Education, 79, 63-75. http://onlinelibrary.wiley.com/doi/10.1002/sce.3730790105/abstract

Gaudreau, N. et al. (2012). The Sense of Personal Efficacy of Teachers and Their Management of the Class and Behaviour Practices. Canadian Journal of Education, 35, 82-101. http://journals.sfu.ca/cje/index.php/cje-rce/article/viewFile/891/1155

Gencer, A. S., \& Çakýroðlu, J. (2007). Turkish Preservice Science Teachers' Efficacy Beliefs Regarding Science Teaching and Their Beliefs about Classroom Management. Teaching and Teacher Education, 23, 664-675.

https://www.researchgate.net/publication/248526693 Turkish preservice science teachers' ef ficacy beliefs regarding science teaching and their beliefs about classroom management

Gerard, F.-M. (2003). The Assessment of the Effectiveness of Training. Management, 20, 13-33. http://www.fmgerard.be/textes/Outil.pdf

Gervais, C. (1999). Conceptual Elements in the Representations of the Actors of a Teaching Internship. Journal of the Science of Education, 25, 271-291.

https://www.erudit.org/revue/rse/1999/v25/n2/032001ar.html?vue=resume

Ginns, W., \& Watters, J. (1999). Beginning Elementary School Teachers and the Effective Teaching of Science. Journal of Science Teacher Education, 10, 287-313. http://citeseerx.ist.psu.edu/viewdoc/download?doi=10.1.1.532.261\&rep=rep1\&type=pdf

Gorrell, J., \& Hwang, Y. S. (1995). A Study of Efficacy Beliefs among Preservice Teachers in Korea. Journal of Research \& Development in Education, 28, 101-105. http://eric.ed.gov/?id=EJ500452

Guittet, A. (2008). Maintenance: Techniques and Practical(8th ed., pp. 9-14). Paris: Collection U. http://www.univ-montp3.fr/infocom/wp-content/REC-Pr\%C3\%A9parer-et-mener-un-entretie $\underline{\mathrm{n} 2010 . \mathrm{pdf}}$

Housego, B. (1992). Monitoring Student Teachers' Feelings of Preparedness to Teach, Personal Teaching Efficacy, and Teaching Efficacy in a New Secondary Teacher Education Program. Alberta Journal of Educational Reasearch, 38, 49-64. http://eric.ed.gov/?id=EJ444968

Hoy, A. W., \& Spero, R. B. (2005). Changes in Teacher Efficacy during the Early Years of Teaching: A Comparison of Four Measures. Teaching and Teacher Education, 21, 343-356. http://dx.doi.org/10.1016/j.tate.2005.01.007

Jonnaert, P. (2002). Skills and Constructivism: A Theoretical Framework (p. 34). Brussels: De Boeck. 
http://www.deboecksuperieur.com/titres/26592 1/9782804134587-competences-et-socioconstr uctivisme.html

Mulholland, J., \& Wallace, J. (2000). Beginning Elementary Science Teaching: Entryways to Different Worlds. Research in Science Education, 30, 155-171. http://link.springer.com/article/10.1007\%2FBF02461626 http://dx.doi.org/10.1007/BF02461626

Mulholland, J., Dorman, J. P., \& Odgers, B. M. (2004).Assessment of Science Teaching Efficacy of Preservice Teachers in an Australian University. Journal of Science Teacher Education, 15, 313-331. http://link.springer.com/article/10.1023/B\%3AJSTE.0000048334.44537.86 http://dx.doi.org/10.1023/B:JSTE.0000048334.44537.86

Perrault, B. (2008). Evaluating Training by Trainees of the First and Second Degrees in IUFM Training (pp. 26-28). A Survey of Trainees from the IUFM.

http://www.Univ-Reims.frformationufr-Instituts-et-ecolesl-IUFM-champagne-ardenneformati onobservatoire-desformationsgalleryfilessite19044011572515730.pdf (the link is not available)

Perrault, B. (2010). The Sense of Personal Effectiveness as an Indicator of the Effectiveness of Training. In Editor IUFM, The Congress of the Topicality of the Research (p. 4). An Application Is the Evaluation of the Training of the Teachers Acts, Geneva: University of Geneva. https://plone.unige.ch/aref2010/communications-orales/premiers-auteurs-en-p/Le\%20sentime nt\%20defficacite.pdf

Perrenoud, P. (2013). Dix nouvelles compétences pour enseigner (7th éd., p. 1). Paris: ESF Éditeur. http://www.unige.ch/fapse/SSE/teachers/perrenoud/php main/php 2001/2001 04.html

Piccoli, G. et al. (2001). Web-Based Virtual Learning Environments: A Research Framework and a Premiminary Assessment of Effectiveness in Basic Skills Training. MIS Quarterly, 25, 401426. http://dx.doi.org/10.2307/3250989

Plourde, L. A. (2002). The Influence of Student Teaching on Preservice Elementary Teachers' Science Selfefficacy and Outcome Expectancy Beliefs. Journal of Instructional Psychology, 29, 245-253.

http://www.freepatentsonline.com/article/Journal-Instructional-Psychology/95148386.html

Riggs, I. M. (1991). Gender Differences in Elementary Science Teacher Self-Efficacy. In Editior US Department of Education, The Annual Meeting of the American Educational Research Association (p. 6). California State University Publisher. http://eric.ed.gov/?id=ED340705

Romano, J. L. (1996). School Personnel Prevention Training: A Measure of Self-Efficacy. Journal of Educational Research, 90, 57-63.

http://www.jstor.org/stable/pdf/27542069.pdf? =1464964716227

http://dx.doi.org/10.1080/00220671.1996.9944444

Schoeneberger, M., \& Russell, T. (1986). Elementary Science as a Little Added Frill: A Report of Two Casestudies. Science Education, 70, 519-538. http://dx.doi.org/10.1002/sce.3730700506

ShkedI, A., \& Laron, D. (2004). Between Idealism and Pragmatism: A Case Study of Student Teachers' Pedagogical Development. Teaching and Teacher Education, 7, 693-711. http://dx.doi.org/10.1016/j.tate.2004.07.006

Tschannen-Moran, M. et al. (1998). Teacher Efficacy: Its Meaning and Measure. Review of Educational Research, 68, 202-224.

http://mxtsch.people.wm.edu/Scholarship/RER TeacherEfficacy.pdf http://dx.doi.org/10.3102/00346543068002202

Wanlin, P. (2007). Recherches Qualitatives-Hors Série-numéro 3. Actes du colloquebilanetprospectives de la recherche qualitative (p. 252). University of Luxemburg Association Pour la recher che qualitative. 
A. Guemri et al.

Yalcin, F. A. (2011). Investigation of Science Teacher Candidates' Self-Efficacy Beliefs of Science Teaching with Respect to Some Variables. International Online Journal of Educational Sciences, 3, 1046-1063.

https://www.researchgate.net/publication/265179504 Investigation of Science Teacher Cand idates' Self-Efficacy Beliefs of Science Teaching with Respect to Some Variables 


\section{Annexes}

Scale of measure of efficacy of trainee teachers (Perrault, 2010) translated by Guemri et al. (2016).

Institution:

You are asked to estimate your level of efficacy for each of the mentioned skills before and after the year of internship training

\begin{tabular}{ccc}
\multicolumn{2}{c}{ Pre-internship } & \multicolumn{2}{c}{ After the internship } \\
\hline $\begin{array}{c}\text { Not } \\
\text { everything } \\
\text { has been able }\end{array}$ & Any fact at able & $\begin{array}{c}\text { Not } \\
\text { everything } \\
\text { has been able }\end{array}$
\end{tabular}$\quad$ Any fact at able

1 Control the disciplinary knowledge necessary to teach Identify links between the disciplines to contribute to their articulation

Identify and appeal to those who can provide help and support in exercise of the profession.

Enter the value of the Tunisian Republic in his professional

4 practice (fight against discrimination, equal opportunities...)

Take into account in his teaching the contributions of school and teaching research.

Act on a daily basis in its class in compliance with the/Regulation (rights, duties of officials, official texts).

7 Be careful to the quality of the language among students.

$8 \quad$ Analyze its business practices.

$9 \quad$ Formulating its vocational training needs.

10 Integrate in its practices of the mastery of oral and written language activities by students

11 Being exemplary in its use of language.

Ensure a framework guaranteeing the safety, security and

12 respect for all students (integrities physical and moral of the students, sanction, authority, justice...)

$13 \quad$ Build a progression of learning

Use tic (information and communication technology) for

14 networking with colleagues ("facebook" social networks, e-mail, forum...)

15

Analyze the observed performance and determine the causes of errors

Teaching with reference to the objectives and content of formal programs of EPS.

Integrate tic (information and

17 communication technology) in sessions with students)

Organize situations learning developing participation and cooperation among students

Create a climate of confidence (attitude, respect, rules, 19 management of conflicts...) in the class supported learning

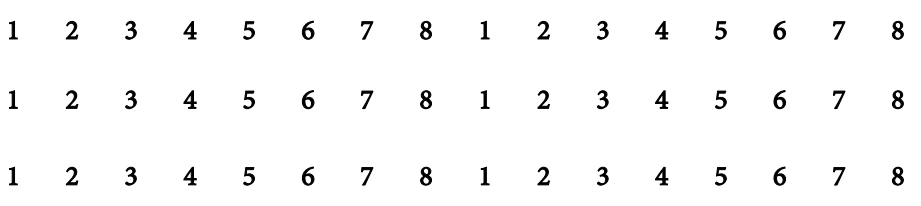

$\begin{array}{llllllllllllllll}1 & 2 & 3 & 4 & 5 & 6 & 7 & 8 & 1 & 2 & 3 & 4 & 5 & 6 & 7 & 8\end{array}$

$\begin{array}{llllllllllllllll}1 & 2 & 3 & 4 & 5 & 6 & 7 & 8 & 1 & 2 & 3 & 4 & 5 & 6 & 7 & 8\end{array}$

$\begin{array}{llllllllllllllll}1 & 2 & 3 & 4 & 5 & 6 & 7 & 8 & 1 & 2 & 3 & 4 & 5 & 6 & 7 & 8\end{array}$

$\begin{array}{llllllllllllllll}1 & 2 & 3 & 4 & 5 & 6 & 7 & 8 & 1 & 2 & 3 & 4 & 5 & 6 & 7 & 8\end{array}$

$\begin{array}{llllllllllllllll}1 & 2 & 3 & 4 & 5 & 6 & 7 & 8 & 1 & 2 & 3 & 4 & 5 & 6 & 7 & 8\end{array}$

$\begin{array}{llllllllllllllll}1 & 2 & 3 & 4 & 5 & 6 & 7 & 8 & 1 & 2 & 3 & 4 & 5 & 6 & 7 & 8\end{array}$

$\begin{array}{llllllllllllllll}1 & 2 & 3 & 4 & 5 & 6 & 7 & 8 & 1 & 2 & 3 & 4 & 5 & 6 & 7 & 8\end{array}$

$\begin{array}{llllllllllllllll}1 & 2 & 3 & 4 & 5 & 6 & 7 & 8 & 1 & 2 & 3 & 4 & 5 & 6 & 7 & 8\end{array}$

$\begin{array}{llllllllllllllll}1 & 2 & 3 & 4 & 5 & 6 & 7 & 8 & 1 & 2 & 3 & 4 & 5 & 6 & 7 & 8\end{array}$ $\begin{array}{llllllllllllllll}1 & 2 & 3 & 4 & 5 & 6 & 7 & 8 & 1 & 2 & 3 & 4 & 5 & 6 & 7 & 8\end{array}$ $\begin{array}{llllllllllllllll}1 & 2 & 3 & 4 & 5 & 6 & 7 & 8 & 1 & 2 & 3 & 4 & 5 & 6 & 7 & 8\end{array}$ $\begin{array}{llllllllllllllll}1 & 2 & 3 & 4 & 5 & 6 & 7 & 8 & 1 & 2 & 3 & 4 & 5 & 6 & 7 & 8\end{array}$ $\begin{array}{llllllllllllllll}1 & 2 & 3 & 4 & 5 & 6 & 7 & 8 & 1 & 2 & 3 & 4 & 5 & 6 & 7 & 8\end{array}$ $\begin{array}{llllllllllllllll}1 & 2 & 3 & 4 & 5 & 6 & 7 & 8 & 1 & 2 & 3 & 4 & 5 & 6 & 7 & 8\end{array}$ $\begin{array}{llllllllllllllll}1 & 2 & 3 & 4 & 5 & 6 & 7 & 8 & 1 & 2 & 3 & 4 & 5 & 6 & 7 & 8\end{array}$ $\begin{array}{llllllllllllllll}1 & 2 & 3 & 4 & 5 & 6 & 7 & 8 & 1 & 2 & 3 & 4 & 5 & 6 & 7 & 8\end{array}$ 


\section{Continued}

20

Choose pedagogic and didactic means (group work, media...) adapted to the learning objectives

To evaluate the skills of the common-base (the common

21 base of knowledge and skills this what all students should know and master at the end of compulsory schooling)

22

Adapt the conduct of the meeting on the basis of the effective work of the students

23

Design at the different times of learning assessment to make account of student assessment

Build learning situations based on skills to provide skills to students

25 Use ICT (information and communication technology) to update his knowledge and develop

26 Choose teaching situations that involve students in learning

27 Differentiate his practice according to the needs of students

28 Build relationships with external partners (sporting, artistic

28 or cultural projects, relations with the professional world...)

29 Develop with colleagues from projects in the school or the establishment

Being able to integrate students with special needs

$$
\text { or with disabilities }
$$

Dialogue with the parents or families on his teaching and on the monitoring of students

Ensure follow-orientation of students in collaboration with

32 relevant institutional partners (counselling, medical-social services, protection of childhood...)

33 Adapt the content of the meeting so as to advance each student

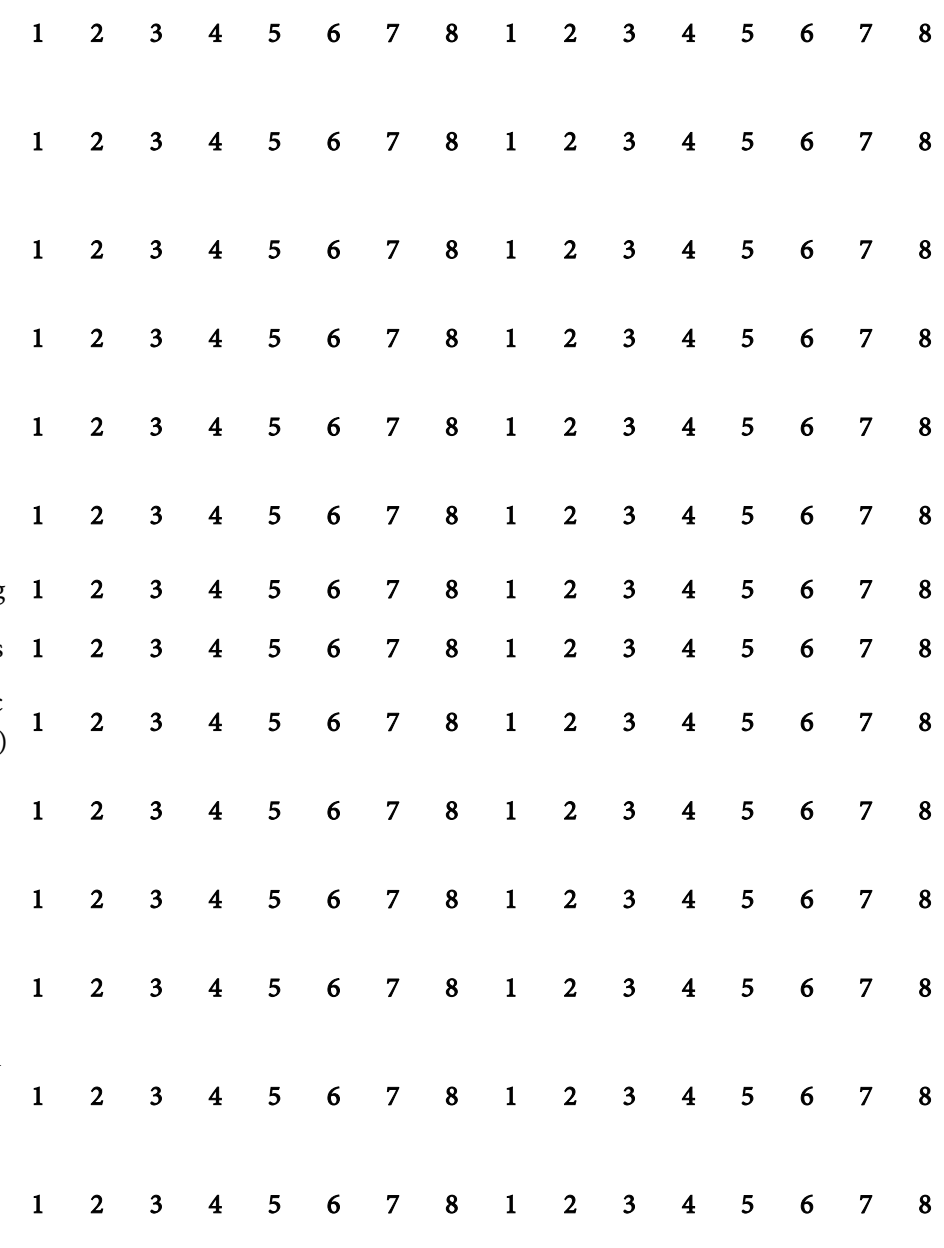

Maintenance for the Pedagogical Advisor

Question 1: act on official State and an ethical and responsible way

Question 2: master the French language to teach and communicate

Question 3: master the disciplines and have a good general culture

Question 4: design and implement his teaching

Question 5: organising the work of the class

Question 6: take into account the diversity of the students

Question 7: assess students

Question 8: master the technologies of information and communication 
Question 9: work as a team and cooperate with parents and partners of school

Question 10:develop and innovate

Suggestions:

Submit or recommend next manuscript to SCIRP and we will provide best service for you:

Accepting pre-submission inquiries through Email, Facebook, LinkedIn, Twitter, etc.

A wide selection of journals (inclusive of 9 subjects, more than 200 journals)

Providing 24-hour high-quality service

User-friendly online submission system

Fair and swift peer-review system

Efficient typesetting and proofreading procedure

Display of the result of downloads and visits, as well as the number of cited articles

Maximum dissemination of your research work

Submit your manuscript at: http://papersubmission.scirp.org/

Or contact ape@scirp.org 